\title{
Middle atmospheric water vapour and dynamics in the vicinity of the polar vortex during the Hygrosonde-2 campaign
}

\author{
S. Lossow ${ }^{1}$, M. Khaplanov ${ }^{1}$, J. Gumbel ${ }^{1}$, J. Stegman ${ }^{1}$, G. Witt ${ }^{1}$, P. Dalin ${ }^{2}$, S. Kirkwood ${ }^{2}$, F. J. Schmidlin ${ }^{3}$, \\ K. H. Fricke ${ }^{4}$, and U. Blum ${ }^{4}$ \\ ${ }^{1}$ Department of Meteorology, Stockholm University, 10691 Stockholm, Sweden \\ ${ }^{2}$ Swedish Institute of Space Physics, 98128 Kiruna, Sweden \\ ${ }^{3}$ NASA Goddard Space Flight Center, Wallops Island, VA 23681, USA \\ ${ }^{4}$ Physikalisches Institut der Universität Bonn, 53115 Bonn, Germany
}

Received: 22 April 2008 - Published in Atmos. Chem. Phys. Discuss.: 20 June 2008

Revised: 25 May 2009 - Accepted: 29 June 2009 - Published: 7 July 2009

\begin{abstract}
The Hygrosonde-2 campaign took place on 16 December 2001 at Esrange/Sweden $\left(68^{\circ} \mathrm{N}, 21^{\circ} \mathrm{E}\right)$ with the aim to investigate the small scale distribution of water vapour in the middle atmosphere in the vicinity of the Arctic polar vortex. In situ balloon and rocket-borne measurements of water vapour were performed by means of $\mathrm{OH}$ fluorescence hygrometry. The combined measurements yielded a high resolution water vapour profile up to an altitude of $75 \mathrm{~km}$. Using the characteristic of water vapour being a dynamical tracer it was possible to directly relate the water vapour data to the location of the polar vortex edge, which separates air masses of different character inside and outside the polar vortex. The measurements probed extra-vortex air in the altitude range between $45 \mathrm{~km}$ and $60 \mathrm{~km}$ and vortex air elsewhere. Transitions between vortex and extra-vortex usually coincided with wind shears caused by gravity waves which advect air masses with different water vapour volume mixing ratios.

From the combination of the results from the Hygrosonde2 campaign and the first flight of the optical hygrometer in 1994 (Hygrosonde-1) a clear picture of the characteristic water vapour distribution inside and outside the polar vortex can be drawn. Systematic differences in the water vapour concentration between the inside and outside of the polar vortex can be observed all the way up into the mesosphere. It is also evident that in situ measurements with high spatial resolution are needed to fully account for the small-scale exchange processes in the polar winter middle atmosphere.
\end{abstract}

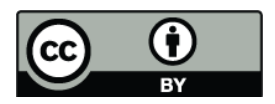

Correspondence to: S. Lossow (stefan.lossow@misu.su.se)

\section{Introduction}

Water vapour plays a major role in the radiative budget and chemistry of the Earth's atmosphere. Recent research on middle atmospheric water vapour has focused on global trends in the stratosphere (e.g. Oltmans et al., 2000; Rosenlof et al., 2001; Nedoluha et al., 2003; Randel et al., 2004; Scherer et al., 2008; Rosenlof and Reid, 2008) and their impacts on the ozone destruction by polar stratospheric clouds (PSC) in the polar vortex (e.g. Rex et al., 2004), tropospherestratosphere exchange (e.g. SPARC, 2000; Sherwood and Dessler, 2000; Bonazzola and Haynes, 2004; Engel et al., 2006; Lelieveld et al., 2006; Fueglistaler et al., 2009), and the water budget in the summer mesopause region (e.g. von Zahn and Berger, 2003; Gordley et al., 2009).

Water vapour enters the middle atmosphere primarily by vertical transport through the tropical tropopause transition layer (TTL) (e.g. Holton et al., 1995; Fueglistaler et al., 2009). The tropical tropopause works as a cold trap where freeze-drying of water vapour and subsequent sedimentation of ice particles strongly reduces the amount of water vapour entering the stratosphere (Brewer, 1949). The water throughput at the tropical tropopause is about $3.7 \mathrm{ppmv}$ (e.g. SPARC, 2000; Nassar et al., 2005) and has a seasonal variation that is governed by the tropopause temperature. The observed temporal evolution is usually referred to as the tape recorder effect (Mote et al., 1996). Besides the transport from the troposphere the only water vapour source in the stratosphere is the oxidation of methane. This production process, however, outweighs the main sink process of water vapour in the stratosphere, i.e. the reaction with $\mathrm{O}\left({ }^{1} \mathrm{D}\right)$. In accordance the water vapour concentration increases with

Published by Copernicus Publications on behalf of the European Geosciences Union. 
altitude in the stratosphere. With increasing altitude the destruction of water vapour by photodissociation becomes increasingly important. Below roughly $70 \mathrm{~km}$ radiation in the Schumann-Runge bands causes the photodissocation of water vapour, at higher altitudes the photodissocation is dominated by Lyman- $\alpha$ radiation $(121.6 \mathrm{~nm})$. The balance between these production and loss processes is usually observed in the vicinity of the stratopause resulting in a maximum in the water vapour concentration ("conventional maximum"). Above in the mesosphere, the concentration of water vapour decreases in general with altitude due to the lack of additional sources. There are two pronounced exceptions from this general mesospheric behaviour which can only occur limited in space and time. The first one is an additional peak between $65 \mathrm{~km}$ and $75 \mathrm{~km}$ occurring both in the tropics around equinox and in the polar region in summer (Nedoluha et al., 1996; Summers et al., 1997; Seele and Hartogh, 1999). This peak is produced by an interplay between dynamics and chemistry during strongest solar insolation, involving upwelling winds and autocatalytical water vapour formation from the molecular hydrogen reservoir (Sonnemann et al., 2005). The second peak can be observed around $82 \mathrm{~km}$ in the polar summer and is due to water vapour redistribution by sedimenting ice particles forming noctilucent clouds (NLC) and polar mesospheric summer echoes (PMSE) (Summers et al., 2001; von Zahn and Berger, 2003).

The chemical and vertical transport life time of water vapour in the middle atmosphere are comparable, i.e. in the order of months. Hence, in the absence of condensation, water vapour is a particular suitable tracer of dynamical processes (Brasseur and Solomon, 1998). One typical application is the polar vortex. The wave driven meridional circulation gives rise to large scale subsidence of air inside the polar vortex. In addition the polar vortex edge efficiently prevents horizontal transport of chemical species from the midlatitudes. Both aspects result in significant horizontal contrasts and gradients in the water vapour concentration across the polar vortex edge. At an altitude level in the lower and middle stratosphere the water vapour concentration will be in general higher inside the vortex than outside due to the subsidence of moister air from higher stratospheric levels inside the vortex. This does not take into account possible dehydration effects due to polar stratospheric clouds type II (composed of water ice) (Kelly et al.,1989; Vömel et al., 1995). The influence of the polar vortex on the water vapour distribution extends well into the mesosphere (e.g. Aellig et al., 1996). More recent satellite measurements by the Fourier Transform Spectrometer (FTS) instrument aboard the Canadian ACE/SCISAT-1 satellite (Bernath et al., 2005) observed differences in the water vapour characteristics inside and outside the polar vortex as high as in $77 \mathrm{~km}$ (Nassar et al., 2005). At mesospheric altitudes the water vapour concentration will be in general lower inside the polar vortex than outside polar vortex due to the subsidence of drier air masses from above inside the polar vortex.
The polar vortex edge is not a simple, well-defined discontinuity, but tends to exhibit layering and filamentation. This is visible as lamination in tracer profiles (Reid and Vaughan, 1991). On the global scale these layering and filamentation structures are caused by irreversible planetary wave breaking at the vortex edge. Filaments are stretched by the polar jet and will be gradually dissipated or mixed with mid-latitude air. On smaller scales also gravity waves can modulate the location of the polar vortex edge and cause lamination structures in tracer profiles. These waves can, in general, only influence tracer profiles in regions where the tracer concentration exhibits strong vertical or horizontal gradients due to advection of air masses with different characteristics.

In order to resolve such small scale dynamical structures, as observed in the vicinity of the polar vortex edge, high resolution in situ measurements are necessary. These measurements are an important complement to ground-based and satellite-borne measurements as well for the evaluation of models. The vertical resolution of ground-based radiometer measurements is not sufficient to resolve small scale structures. In order to increase the signal-to-noise ratio these measurements usually need to be integrated over a longer period of time during which small scale structures could have changed already. Satellite data represent a mean over a horizontal path of several hundred kilometres at the single tangent heights. This makes it very difficult to analyse local structures, especially when there are strong horizontal gradients present as at the edge of the polar vortex. Also results from the ECMWF (European Centre for Medium-range Weather Forecast) model do not characterise satisfactorily the water vapour distribution in the polar vortex edge region in the lower and middle stratosphere (Maturilli et al., 2006). High resolution in situ measurements of water vapour are well established in the lower and middle stratosphere. Higher up, in the upper stratosphere and mesosphere, such measurements are extremely rare. In this paper we present a high resolution water vapour measurement from the Hygrosonde2 campaign in the vicinity of the polar vortex, covering the middle atmosphere up to an altitude of $75 \mathrm{~km}$. This campaign is a continuation of the measurements performed during the Hygrosonde-1 campaign in 1994 (Khaplanov et al., 1996). In the next section we give a brief introduction of the principle behind the high-resolution water vapour measurement. In Sect. 3 we give an overview of the observations and describe the results in Sect. 4. The subsequent discussion in Sect. 5 also includes a comparison to the results from the Hygrosonde-1, with focus on the water vapour distribution in the vicinity of the polar vortex. 


\section{Water vapour measurements}

\subsection{Measurement principle}

The high resolution in situ water vapour measurements during the Hygrosonde- 2 campaign were performed both from balloon and sounding rocket and are based on $\mathrm{OH}$ fluorescence hygrometry (Kley and Stone, 1978; Khaplanov et al., 1992 and 1996). This technique employs active dissociation of water vapour at wavelengths below $137 \mathrm{~nm}$ by a vacuum ultraviolet (VUV) light source in order to produce electronically excited $\mathrm{OH}^{*}\left(\mathrm{~A}^{2} \Sigma^{+}\right)$. This excited hydroxyl radical subsequently returns to its ground state $\left(X^{2} \Pi\right)$ emitting primarily in the wavelength range between $306 \mathrm{~nm}$ and $326 \mathrm{~nm}$. From the intensity $I$ of this emission the actual water vapour concentration $C_{\mathrm{H}_{2} \mathrm{O}}$ can be derived according to:

$I=K \cdot Q \cdot C_{\mathrm{H}_{2} \mathrm{O}}$

Here, $K$ is a hygrometer specific constant comprising various aspects, such as the photon flux of the VUV light source, the geometry and spectral response of the detection system, as well as the quantum yield and water absorption cross section. This constant has to be determined individually for every hygrometer by calibration efforts. The calibration of $K$ has been carried out in a vacuum chamber against predetermined water vapour concentrations. The total pressure during the calibrations has been maintained below $0.01 \mathrm{hPa}$, ensuring the absence of quenching of the $\mathrm{OH}^{*}\left(\mathrm{~A}^{2} \Sigma^{+}\right)$excited state. Pressure-dependent quenching is the other important component that determines the decay of the excited $\mathrm{OH}^{*}\left(\mathrm{~A}^{2} \Sigma^{+}\right)$state besides fluorescence. In the Earth's atmosphere this process becomes important below about $60 \mathrm{~km}$ in this particular case. This is taken into account in equation 1 by $Q$, the quenching factor, which describes the relative importance of emission and quenching as competing processes responsible for the decay of $\mathrm{OH}^{*}\left(\mathrm{~A}^{2} \Sigma^{+}\right)$. At pressures where quenching can be neglected the quenching factor $Q$ gets 1 . For the Hygrosonde instruments $Q$ has been calculated as a function of atmospheric pressure. These calculations have been based on a comprehensive study of the collisional quenching processes employing laboratory measurements in a fluorescence chamber and model simulations. Detailed information about this study can be found in Gumbel (1997). Overall, we estimate that the systematic uncertainty of the Hygrosonde instruments is within $10 \%$.

\subsection{Instrument aspects}

The water vapour measurements require an uncontaminated measurement volume. Hence, outgassing and desorption of water vapour from the payload itself are major challenges, especially for the rocket-borne measurements. For the rocket-borne experiment the key to undisturbed data is therefore to perform the measurements in a volume that is not influenced the payload itself, i.e. outside the rocket shock front. The shock front keeps contaminations due to outgassing and desorption away from the measurement volume (Khaplanov et al., 1996). This measurement technique is optimised for ascent part of the rocket flight where the aerodynamic concept is usually fulfilled. On the descent the rocket is usually not stabilised so that undisturbed measurements outside the shock front are only available from the parts of the trajectory with aerodynamically favourable payload orientations. Contrary to the rocket-borne measurements the balloon measurements are favoured on the relatively fast descent, when all sources of contamination are downstream the instrument. On the ascent desorption from the balloon and gondola might contaminate the measurements, depending on the weather conditions during the launch. To optimise the balloon measurements and reduce possible contaminations even further the instrument looked downwards.

Both, the balloon and rocket-borne instrument used a Lyman- $\alpha$ light source for the active dissociation of water vapour. The rocket hygrometer had been significantly improved compared to the instrument used during the Hygrosonde-1 campaign. In total the sensitivity of the Hygrosonde-2 rocket hygrometer was about 20-times higher than for its predecessor. This improvement was based on two important changes. The major change was a new hydrogen lamp which comprised six capillary discharges inside a single lamp body. This lamp has been developed especially for this instrument at the Vavilov State Optical Institute in St. Petersburg, Russia. The second important change concerned the lamp modulation. This modulation is employed to discriminate the fluorescence signal from the background and has been changed from a symmetrical (1/2) to an asymmetrical duty cycle (1/8). While the integral output of the lamp is limited this asymmetrical cycle allows stronger pulses. At the same time the time period for the background determination is extended. This change of the lamp modulation increased significantly the signal-to-noise ratio, especially for the measurements in the mesosphere. The balloon hygrometer employed only a single discharge lamp since the measurements in the troposphere and lower stratosphere do not require such a high sensitivity as needed higher up in the stratosphere and mesosphere.

The raw data were read out every $2.5 \mathrm{~ms}$ from the rocketborne instrument. In order to further increase the signal-tonoise ratio the raw data were then integrated over a period of $0.3 \mathrm{~s}$. Hence, the effective altitude resolution of the water vapour data depends on the rocket velocity. At $40 \mathrm{~km}$, for example, the effective altitude resolution was about $300 \mathrm{~m}$, while the resolution was about $200 \mathrm{~m}$ at $70 \mathrm{~km}$. The water vapour data from the balloon measurement were read out every four seconds. No smoothing has been applied to these data. Assuming a typical balloon ascent rate of $5 \mathrm{~m} \cdot \mathrm{s}^{-1}$ yields a vertical resolution of $20 \mathrm{~m}$ for this measurement. 


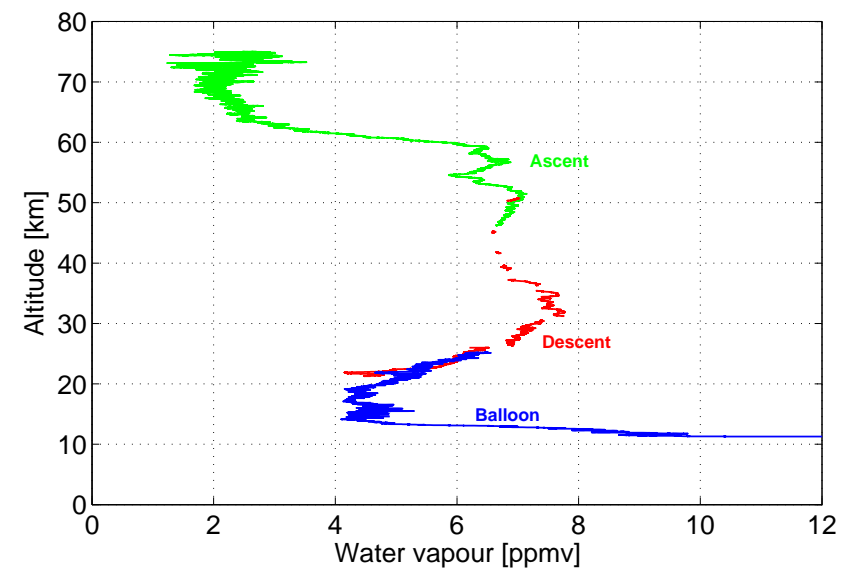

Fig. 1. The water vapour profile derived during the Hygrosonde2 campaign on 16 December 2001 at Esrange $\left(68^{\circ} \mathrm{N}, 21^{\circ} \mathrm{E}\right)$ by means of $\mathrm{OH}$ fluorescence hygrometry. The Skerries balloon measurements (ascent) are shown in blue, the rocket measurements on the ascent in green and on the descent in red.

\section{Experiments}

The Hygrosonde- 2 campaign comprised a comprehensive set of experiments to measure the middle atmospheric water vapour concentration and the background state of the atmosphere.

The main Hygrosonde- 2 rocket payload, carrying one of the hygrometers, was launched on 16 December 2001, 05:12 UT, reaching a top altitude of $90 \mathrm{~km}$. This rocket carried also solid particle impact detectors from the University of Colorado (Horányi et al., 2000). For results from this experiment the reader is referred to Robertson et al. (2004). The Skerries balloon of the Swedish Institute for Space Physics in Kiruna was carrying the second hygrometer (Khaplanov et al., 2001). The balloon was launched at 04:58 UT and overlapped with the main rocket flight in time. It reached a top altitude of $25 \mathrm{~km}$, providing also profiles of temperature, winds and density. Two meteorological rockets from NASA's Wallops Space Flight Center carrying falling spheres were launched right after the major Hygrosonde-2 rocket at 05:43 UT and 06:18 UT, respectively. These rocket measurements provided temperature, winds and density in the upper stratosphere and mesosphere (Schmidlin et al., 1991). The weather conditions (cloud cover) allowed only occasional measurements of the Bonn University Rayleigh/Raman lidar (UBonn Lidar, Blum and Fricke, 2005) during the night. In total three hours of measurement were possible. These lidar measurements provided density and temperature profiles and monitoring of PSC presence. Complementary meteorological data have been obtained from the ECMWF.

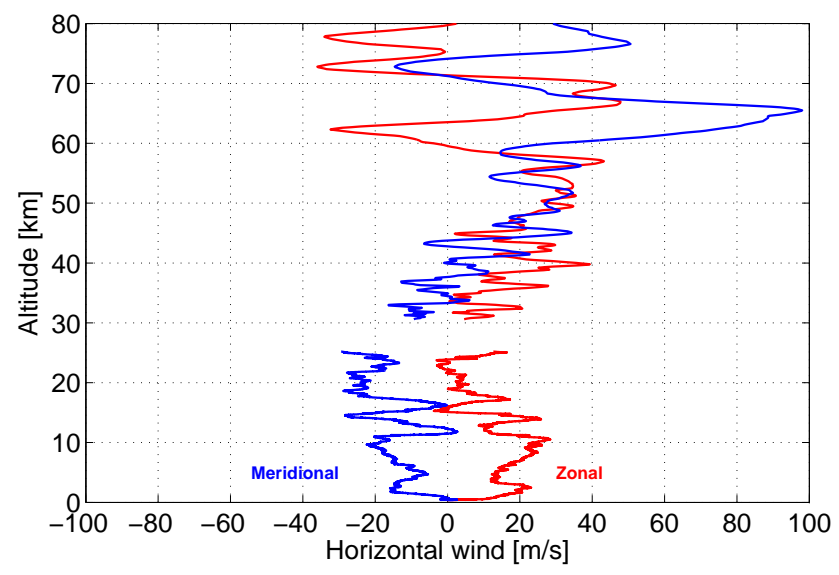

Fig. 2. Zonal (from $\mathrm{W}$ to $\mathrm{E}$ ) and meridional (from $\mathrm{S}$ to $\mathrm{N}$ ) winds measured by the Skerries balloon (below $25 \mathrm{~km}$ ) and the second falling sphere (above $31 \mathrm{~km}$ ), launched at 06:18 UT.

\section{Results}

\subsection{Local measurements}

Figure 1 shows the combined water vapour profile measured during the Hygrosonde- 2 campaign with the balloon and rocket-borne hygrometers. The balloon measurements (blue) covered the altitude range up to $25 \mathrm{~km}$. Here, data from the ascent of the balloon are shown. These data coincided better in time and space with rocket-borne observations than the data from descent part of the balloon flight. Water vapour measurements on the ascent of the rocket flight (green) were available above $45 \mathrm{~km}$, after the opening of the rocket's nose cone. The water vapour profile from the ascending flight is shown up an altitude of $75 \mathrm{~km}$. Up to this altitude it could be definitely assured that the measurements were made outside the shock front and were not influenced by contaminations from outgassing and desorption. Higher up the measured signal increases rapidly due to contaminations and the derived water vapour is therefore not shown here. The descending flight (red) provided data down to an altitude of $22 \mathrm{~km}$. Contaminations from outgassing and desorption have been observed on the descent, as described in Sect. 2.2. These perturbed parts of the descent profile are not shown (gaps in the profile). The spread of the data shown in Fig. 1 represents its statistical uncertainty. This uncertainty increases almost exponentially with altitude in the upper altitude domain presented here. At $50 \mathrm{~km}$ the statistical uncertainty of the water vapour data is about $0.04 \mathrm{ppmv}$, at $60 \mathrm{~km}$ about $0.1 \mathrm{ppmv}$ while the statistical uncertainty amounts to approximately $0.3 \mathrm{ppmv}$ at $70 \mathrm{~km}$.

The water vapour concentration exhibits a sharp decrease in the upper troposphere and tropopause region. The hygropause is located at about $14 \mathrm{~km}$, approximately $3 \mathrm{~km}$ above the tropopause, with a concentration of slightly more than 4.0 ppmv. The observed water vapour volume mixing 


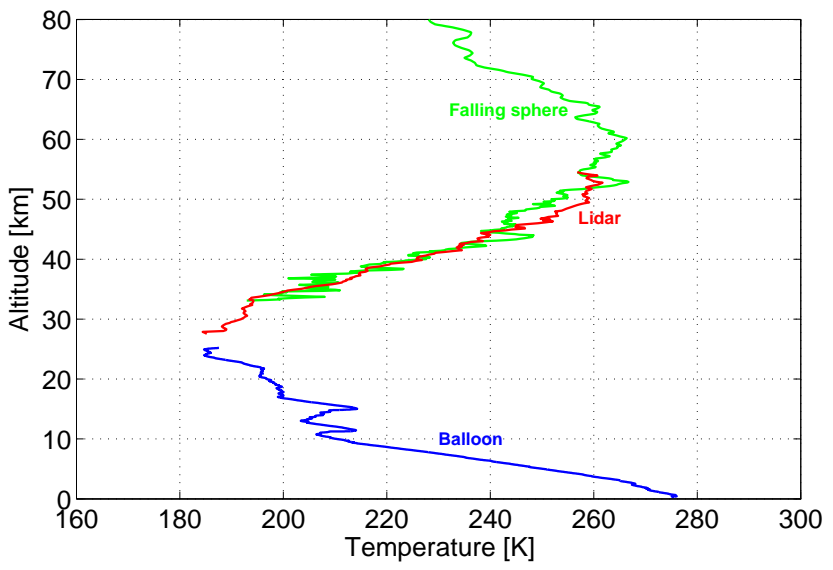

Fig. 3. Temperature profile derived from falling sphere (green), lidar (red) and balloon measurements (blue). The lidar temperature is a mean over three hours of measurements.

ratio increases strongly between $20 \mathrm{~km}$ and $30 \mathrm{~km}$, from around 4 ppmv to more than 7 ppmv. A maximum can be observed at about $32 \mathrm{~km}$. Above $32 \mathrm{~km}$ the water vapour concentration decreases slightly with altitude, but recovers at an altitude of about $45 \mathrm{~km}$. A second, but weaker, maximum can be observed at approximately $52 \mathrm{~km}$. In a thin layer above, the water vapour concentration drops by around 1 ppmv, reaching a local minimum at an altitude of $55 \mathrm{~km}$. At about $57 \mathrm{~km}$ a third distinct water vapour maximum is observable. Above $60 \mathrm{~km}$ the water vapour concentration decreases rapidly from more than $6 \mathrm{ppmv}$ to around 2 ppmv at $70 \mathrm{~km}$.

The measured profiles of the zonal (from W to E, red) and meridional (from $\mathrm{S}$ to $\mathrm{N}$, blue) wind components are plotted in Fig. 2. The profiles in the troposphere and lower stratosphere are based on the ascent data from the Skerries balloon, above $31 \mathrm{~km}$ the data are taken from the measurements by the second falling sphere. The statistical error of zonal wind is about $1 \mathrm{~m} \cdot \mathrm{s}^{-1}$ or even better below $40 \mathrm{~km}$, but increases with increasing altitude. The error of the meridional wind exhibits the same behaviour. At $80 \mathrm{~km}$ the zonal wind error is less than $8 \mathrm{~m} \cdot \mathrm{s}^{-1}$, while the statistical error of the meridional wind amounts to about $5 \mathrm{~m} \cdot \mathrm{s}^{-1}$ at this altitude. The wind measurements exhibit wave structures almost in the entire altitude of concern here, clearly marking the influence of gravity waves. Most prominent is the strong wind shear in the altitude range between $60 \mathrm{~km}$ and $70 \mathrm{~km}$.

The temperature profile shown in Fig. 3 combines the measurements from the balloon ascent (blue), the second falling sphere (green) and the lidar instrument (red). The lidar measurements allowed a temperature derivation above $28 \mathrm{~km}$. At this lower end the statistical error of the derived temperature is less than $1 \mathrm{~K}$, however the error increases with increasing altitude. We do not show the lidar temperature above $54 \mathrm{~km}$ where the corresponding statistical error ex- ceeded $5 \mathrm{~K}$. The statistical error of the temperature derived from the falling sphere measurement is typically below $2 \mathrm{~K}$. The tropopause was located at about $11 \mathrm{~km}$ altitude, based on the dynamical definition using the potential vorticity criterion of $2 \mathrm{PVU}\left(1 \mathrm{PVU}=10^{-6} \mathrm{~K} \cdot \mathrm{m}^{2} \cdot \mathrm{kg}-1 \cdot \mathrm{s}-1\right)$. The absolute minimum temperature could be observed slightly below $25 \mathrm{~km}$ with somewhat less than $185 \mathrm{~K}$. Such low temperatures in this altitude region allow the formation and sustainment of PSC. The lidar measurements confirmed the presence of a PSC layer in this altitude region. The absolute maximum temperatures could be observed at about $53 \mathrm{~km}$ and $60 \mathrm{~km}$, at both altitudes the falling sphere measurements showed a temperature of $266 \mathrm{~K}$. Like in the wind profiles clear signs of gravity wave activity can be observed in the temperature.

\subsection{Polar vortex situation}

During most of November 2001 the Arctic polar vortex has been strong and symmetrical in the stratosphere. On 30 November 2001 a minor warming occurred which disappeared on 8 December 2001. The vortex recovered in the following days until an early major stratospheric warming occurred on 20 December 2001. This early warming was caused by the breaking of quasi-stationary waves (wave number 1) due to large-scale waves, which were propagating westward through the stratosphere. These propagating waves had been initialized by strong tropospheric blockings which could be observed one to two weeks prior the warming (Naujokat et al., 2002).

The operational ECMWF data set for 06:00 UT on 16 December 2001 provides a nearly realtime overview of the polar vortex situation during the Hygrosonde- 2 campaign. Below $430 \mathrm{~K}$ potential temperature $(\sim 18 \mathrm{~km})$ the polar vortex was not developed. The ECMWF data exhibits a developing, quite deformed polar vortex in the altitude range between $430 \mathrm{~K}$ and $530 \mathrm{~K}(\sim 23 \mathrm{~km})$. Above this altitude up to $850 \mathrm{~K}$ potential temperature $(\sim 32 \mathrm{~km})$ a pronounced polar vortex could be observed. Information about the vortex situation at higher altitudes is not included operational ECMWF data set. Figure 4 shows the modified potential vorticity (Lait, 1993) field at the $850 \mathrm{~K}$ potential temperature level. As normalisation level the $475 \mathrm{~K}$ potential temperature level has been used. The two thick black contour lines describe the vortex edge region according to the criteria given by Nash et al. (1996). The vortex edge region is defined by the region between the local minimum and local maximum of the second derivative the potential vorticity around the mean polar vortex edge. The mean polar vortex edge itself is defined by the maximum gradient in the potential vorticity constrained by the co-location of the maximum of the wind velocity. While the vortex edge is pronounced over Alaska, Siberia and northern Europe, it is somewhat disturbed over the Atlantic and Northern America. Here, non-vortex air could possibly enter the polar vortex area. Applying the criteria given 
Table 1. Overview of the gravity wave parameters determined by the hodograph analysis in three selected altitude ranges.

\begin{tabular}{lrrr}
\hline Altitude range [km] & $13.8-17.5$ & $44.2-47.7$ & $57.0-67.6$ \\
\hline Period [h] & 6.9 & 5.7 & 8.2 \\
Horizontal wavelength [km] & 370 & 261 & 1100 \\
Vertical wavelength [km] & 3.7 & 3.5 & 10.6 \\
Intrinsic horizontal phase velocity [m/s] & 15 & 13 & 38 \\
Intrinsic vertical phase velocity [m/s] & -0.15 & -0.17 & -0.36 \\
\hline
\end{tabular}

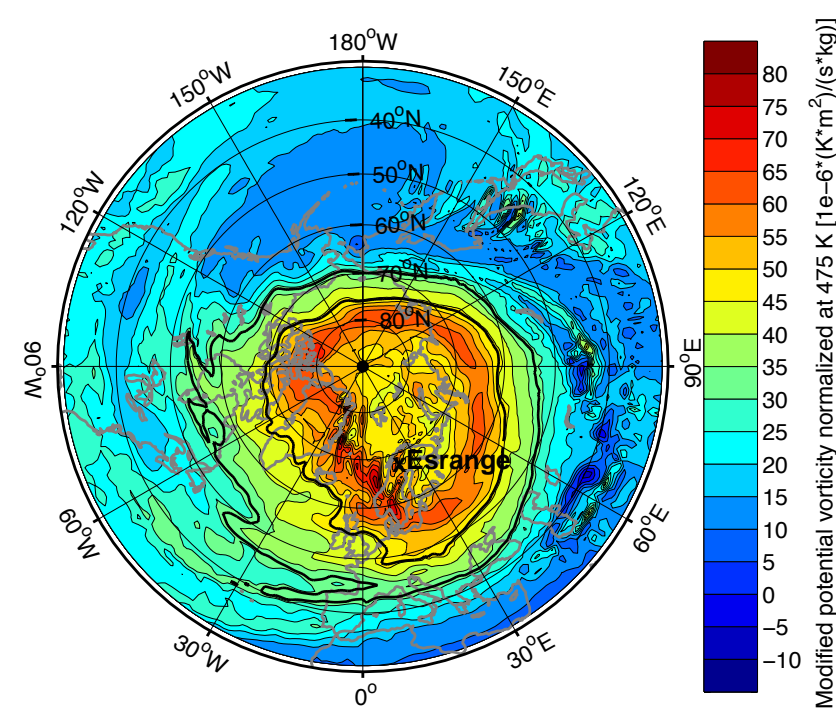

Fig. 4. The distribution of the modified potential vorticity at the $850 \mathrm{~K}$ potential temperature level $(\sim 32 \mathrm{~km})$ based on the ECMWF operational data at 06:00 UT on 16 December 2001. The normalisation level has been $475 \mathrm{~K}$. The two thick contour lines mark the polar vortex boundary region according to the criterion defined by Nash et al. (1996).

by Nash et al. (1996) to the ECMWF operational data the location of the Esrange was inside the polar vortex in the altitude range above $500 \mathrm{~K}(\sim 22 \mathrm{~km})$ up to $850 \mathrm{~K}$ potential temperature.

\subsection{Gravity wave activity}

The presence of gravity waves can clearly be seen in the local temperature and wind measurements. In order to determine the dominant waves we applied a hodograph analysis (e.g. Hirota and Niki, 1986) to the measured wind data. From the data we selected those altitude ranges where nearly monochromatic waves could be observed, namely $13.8 \mathrm{~km}$ to $17.5 \mathrm{~km}, 44.2 \mathrm{~km}$ to $47.7 \mathrm{~km}$ and $57.0 \mathrm{~km}$ to $67.6 \mathrm{~km}$. The derived wave parameters in these three altitude ranges are summarised in Table 1. In all three altitude ranges selected, quasi-stationary waves can be observed. The term "quasi" refers to the fact that we observe these waves only at single time and location and thus do not have any information about their time development. The clockwise rotation of the wind indicates upward propagating waves and energy, while the gravity wave phase moves downward. The waves observed in the lower and upper stratosphere have very similar characteristics in terms of vertical wavelength and intrinsic phase velocities. The wave observed in the mesosphere exhibits a different character with a much longer horizontal and vertical wavelength and might be of different origin than the waves observed at lower altitudes. However, the data do not contain any conclusive information about where and by which process the observed waves have been excited and we can only speculate here. We can rule out an excitation by the local jet stream below the tropopause since no pronounced jet can be observed in the measured wind. However we cannot rule out this excitation process at other remote locations. A likely scenario is that these waves have been induced orographically by the Scandinavian mountain ridge which is the major excitation source in this area. The conditions for such excitation have been optimal between 9 December and 16 December 2001 without any exception. This can be concluded from the analysis of ECMWF data in accordance to criteria defined by Dörnbrack et al. (2001). Their criteria are intended to determine the possibility of gravity wave excitation by the Scandinavian mountain ridge based on the horizontal wind velocity and its turning with altitude. Again, an orographical excitation of the observed waves at a remote location, like Greenland for example, is also possible.

\section{Discussion}

The water vapour distribution observed during the Hygrosonde-2 campaign shows some special characteristics, with respect to the general water vapour distribution described in the Sect. 1. The observations exhibit three distinct maxima in the water vapour concentration at about $32 \mathrm{~km}, 52 \mathrm{~km}$ and $57 \mathrm{~km}$. We suggest that this aspect reflects measurements probing both vortex and extra-vortex air in different altitude ranges.

In the altitude range between $15 \mathrm{~km}$ and $19 \mathrm{~km}$ the observed water vapour concentration is rather constant with altitude. This is usually an indication of extra-vortex conditions. Typical water vapour concentrations outside the polar vortex range between $4 \mathrm{ppmv}$ and $5 \mathrm{ppmv}$ in the altitude range between $16 \mathrm{~km}(\sim 400 \mathrm{~K}$ potential temperature $)$ and 
$26 \mathrm{~km}(\sim 600 \mathrm{~K})$ (e.g. de la Noë et al., 1999; Maturilli et al., 2006). This is consistent with the ECMWF operational data which indicates that for most of the altitude range between $15 \mathrm{~km}$ and $19 \mathrm{~km}$ the polar vortex was not developed at all. From about $4.2 \mathrm{ppmv}$ at $19 \mathrm{~km}$ altitude the water vapour concentration is increasing steadily to the first maximum at about $32 \mathrm{~km}$, where a concentration of $7.7 \mathrm{ppmv}$ can be observed. This strong increase in the lower and middle stratosphere is in general typical for the conditions inside the polar vortex (Maturilli et al., 2006). This conclusion is also supported by the analysis of the vortex edge location based on the criteria defined by Nash et al. (1996) using ECMWF operational data. This analysis showed that the location of the Esrange was inside the polar vortex somewhat above $22 \mathrm{~km}$ ( $\sim 500 \mathrm{~K}$ potential temperature). The discrepancy in altitude above which the location of the Esrange is inside the polar vortex is likely attributed to the rather coarse vertical and horizontal resolution of the ECMWF model in comparison to the smaller scale changes across the polar vortex edge. As a small scale deviation from the vortex inside picture drawn above, the observed water vapour profile exhibits a small bite-out slightly below $22 \mathrm{~km}$. The balloon measurement show a minimum concentration of about $4.6 \mathrm{ppmv}$ in this very thin layer, which is characteristic for conditions outside the polar vortex as described above.

The observed maximum in the water vapour concentration at $32 \mathrm{~km}$ represents the conventional water vapour maximum for conditions inside the vortex, which is shifted downward due to the large scale subsidence of air inside the polar vortex. The observed altitude of the conventional maximum is somewhat lower than the examples found in the literature. Observations by ACE/FTS from 2004 show this water vapour peak slightly below $40 \mathrm{~km}$ altitude (Nassar et al., 2005). Aellig et al. (1996) report about measurements of the Millimeter-wave Atmospheric Sounder (MAS, Croskey et al., 1992) where they observed the maximum at about $1200 \mathrm{~K}$ potential temperature, which corresponds to an altitude of approximately $37 \mathrm{~km}$. Results from the Polar Ozone and Aerosol Measurement (POAM) III instrument (Lucke et al., 1999) show occasionally a similar altitude of the conventional water maximum inside the polar vortex as our observation. In the average they find this maximum at an altitude of about $35 \mathrm{~km}$ in the Arctic winters between 1998/1999 and 2000/2001 (Nedoluha et al., 2002).

Up to an altitude of about $45 \mathrm{~km}$ the water vapour concentration decreases and the measurement has been performed inside the vortex. Above $45 \mathrm{~km}$ the water vapour concentration recovers, indicating that the measurement was made outside the polar vortex in this altitude range. At the transition altitude between vortex and extra-vortex at about $45 \mathrm{~km}$ also a nearly monochromatic gravity wave has been observed (see Table 1) which was likely involved in the modulation of the polar vortex edge and the advection of extra-vortex air. The second water vapour maximum at $51.5 \mathrm{~km}$ represents the conventional water vapour maximum for conditions outside the polar vortex. The maximum exhibits a concentration of $7.1 \mathrm{ppmv}$. This can be compared to typical water vapour concentrations inside the polar vortex that range between 3 ppmv and 5 ppmv in this altitude range, according to ACE/FTS observations (Nassar et al., 2005). A pronounced drop in the water vapour concentration above the second maximum results in a minimum at about $55 \mathrm{~km}$. This minimum exhibits a water vapour concentration of 5.9 ppmv. Again, distinct gravity wave activity is evident in the wind and temperature distribution in this altitude region. The observed water vapour concentration at this minimum is distinctly higher than those typical concentrations inside the polar vortex determined by ACE/FTS. This may indicate that only air from the edge between vortex and extra-vortex or the edge of a filament has been advected at this altitude. Higher up the water vapour concentration recovers and at $57 \mathrm{~km}$ a third distinct maximum ( $6.8 \mathrm{ppmv})$ in the observed water vapour distribution can be found. This third maximum is only part of the expected water vapour decrease above the extra-vortex conventional water vapour maximum around the stratopause. Then a sudden steep decrease of the water vapour concentration occurs around $60 \mathrm{~km}$, connected to a gravity wave induced very strong wind shear. At $70 \mathrm{~km}$ a concentration of only 2 ppmv remains, a typical value for air from inside the polar vortex. Since the wind changed its direction from southwest to southeast, it can be concluded that vortex air was located southeast from the Esrange in this altitude range. Above $70 \mathrm{~km}$ the water vapour concentration recovers towards values which tend to be more representative for the extra-vortex, as observed by ACE/FTS.

The combination of the Hygrosonde- 1 and Hygrosonde-2 campaign results provides a very instructive and unique picture of the middle atmospheric water vapour distribution in the vicinity of the Arctic polar vortex, even if these measurements just present snap shots. Figure 5 shows the water vapour distribution as observed during both campaigns. The Hygrosonde-1 campaign consisted only of a single rocket flight carrying the hygrometer. The rocket was launched on 5 December 1994 at 00:50 UT from the Esrange and reached a top altitude of $77 \mathrm{~km}$. The water vapour distribution could effectively be determined in the altitude range between $25 \mathrm{~km}$ and $68 \mathrm{~km}$. Unfortunately no additional temperature and wind measurements supported the first Hygrosonde experiment, i.e. some statements about wave activity in the vicinity of the polar vortex edge can only made from the water vapour measurement itself. More detailed information about the Hygrosonde- 1 campaign can be found in Khaplanov et al. (1996).

As evident from Fig. 5 the dynamical situation during Hygrosonde-1 was different in comparison to Hygrosonde2. In contrast to the Hygrosonde- 2 measurements, which have been performed inside the polar vortex below $40 \mathrm{~km}$, the Hygrosonde-1 measurement probed extra-vortex air in this altitude range. The analysis of the polar vortex edge location according to Nash et al. (1996), employing 40 year 


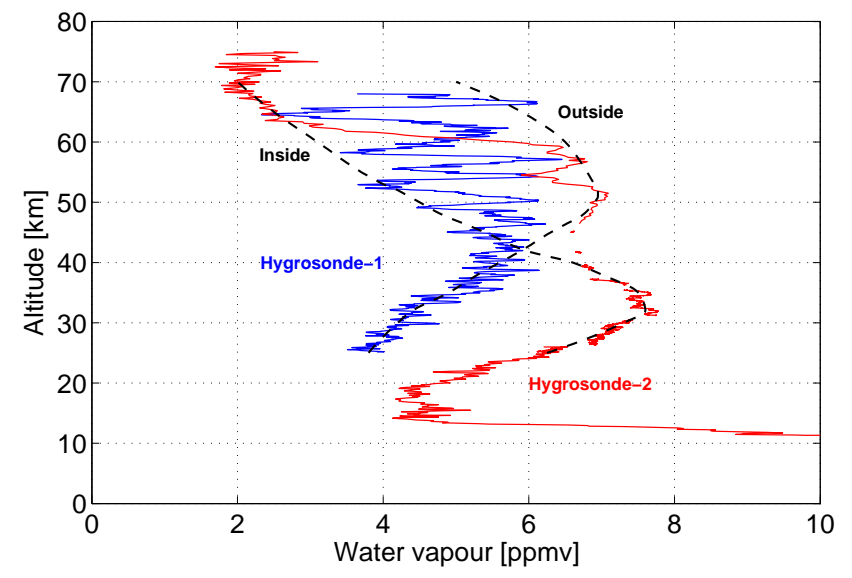

Fig. 5. The water vapour profiles measured during the Hygrosonde1 (5 December 1994) and Hygrosonde-2 campaigns at Esrange. The dashed lines represent typical water distributions inside and outside the polar vortex that are consistent with the measurements from these two campaigns.

reanalysis data from ECMWF (Uppala et al. 2005), confirms this conclusion below $32 \mathrm{~km}$. In this altitude range the polar vortex is located north of Esrange. At $32 \mathrm{~km}$, the altitude where the conventional maximum inside the polar vortex could be observed during Hygrosonde-2, the difference in the water vapour concentration between the vortex and extra-vortex is about 3.6 ppmv. In comparison, the analysis of ACE/FTS measurements by Nassar et al. (2005) exhibits only a difference of less than 1 ppmv. In the entire altitude range above $45 \mathrm{~km}$ the Hygrosonde- 1 water profile shows strong lamination structures. While the Hygrosonde-1 hygrometer was about 20-times less sensitive as the corresponding Hygrosonde-2 instrument (see Sect. 2.2) aerodynamically favourable payload orientations allowed also measurements on the rocket descent. The consistency of this structure in both the rocket ascent and descent measurements ensure the authenticity of these variations. In the same way as for the Hygrosonde-2 results we suggest that this structure is caused by the influence of gravity waves on the location of the polar vortex edge. In this case a gravity wave with a vertical wavelength of $3 \mathrm{~km}$ to $5 \mathrm{~km}$ influenced the water vapour distribution observed over the Esrange. Wind shears induced by this wave modulated the location of the border (the polar vortex edge) between the two different air masses so that the rocket trajectory crossed this border several times. The water vapour contrasts between the vortex inside and outside suggested by the fluctuations in the Hygrosonde-1 profile are consistent with the vortex/extra-vortex contrasts suggested by Hygrosonde- 2 .

From the result of both Hygrosonde campaigns we can suggest representative profiles of the typical water vapour distribution inside and outside the Arctic polar vortex in the altitude range between $25 \mathrm{~km}$ and $70 \mathrm{~km}$. These representa- tive profiles are shown by the dashed lines in Fig. 5. These typical distributions are in agreement with the ACE/FTS observations as discussed above. Overall, the contrast between vortex and extra-vortex water vapour distributions is rather large. The polar vortex edge, separating two air masses of different water vapour content, appears to be rather sharp and remains sharp up to at least $70 \mathrm{~km}$. In the altitude range between $60 \mathrm{~km}$ and $70 \mathrm{~km}$ the difference in the water vapour concentration between vortex and extra-vortex is in the order of 3 ppmv. The polar vortex is strongly deformed by waves, both planetary and smaller scale gravity waves. The strong gradient of the potential vorticity across the polar vortex edge prevents diffusion and small scale eddy mixing, so that highly isolated areas and filaments can occur and exist for a long time.

Our results provide also a valuable input for future modelling efforts. Current model results show a wide spread in the water vapour distribution in the polar vortex region (Eyring et al., 2006). Furthermore the model calculations show in general not such distinct differences in the water vapour concentration between the vortex and extra-vortex (Eyring et al., 2006). These problems are basically due to an insufficient model resolution which in turn result in difficulties to resolve all wave effects.

\section{Summary}

The Hygrosonde- 2 campaign has provided a detailed picture of the water vapour distribution in the vicinity of the polar vortex. Water vapour as a dynamical tracer has been used to determine the position of the measurement with respect to the polar vortex. This analysis showed that the Hygrosonde- 2 profile has been measured inside the polar vortex in the middle stratosphere and middle mesosphere, while the measurement took place outside the polar vortex in the upper stratosphere and lower mesosphere. Transitions between vortex and extra-vortex usually coincided with wind shears caused by gravity waves. This observation reflects the role of waves at the polar vortex edge in general. They can modulate the location of the polar vortex edge which separates two air masses of different characteristics. In this way these waves can influence the water profile distribution observed over a certain location.

From the results of the Hygrosonde- 1 and Hygrosonde2 campaign we derived typical water vapour profiles which represent the humidity structure inside and outside the polar vortex in the altitude range between $25 \mathrm{~km}$ and $70 \mathrm{~km}$. The conventional water vapour maximum inside the polar vortex is located around $20 \mathrm{~km}$ lower as compared to extra-vortex. In general, the humidity contrasts between vortex and extravortex are rather large. The separating influence of the polar vortex edge on the water vapour distribution continues high up into the mesosphere. At altitudes as high as $70 \mathrm{~km}$ the polar vortex edge still prevents horizontal mixing of the 
different air masses, in agreement with the observations by ACE/FTS.

Acknowledgements. We thank the personnel of Swedish Space Corporation for their help during the Hygrosonde-2 campaign. This work was conducted with support from the Swedish National Space Board. We would like to acknowledge Farah Khosrawi for helpful comments on the manuscript.

Edited by: F.-J. Lübken

\section{References}

Aellig, C. P., Bacmeister, J., Bevilacqua, R. M., Daehler, M., Kriebel, D., Pauls, T., Siskind, D., Kämpfer, N., Langen, J., Hartmann, G., Berg, A., Park, J. H., and Russell III, J. M.: Spaceborne $\mathrm{H}_{2} \mathrm{O}$ observations in the Arctic stratosphere and mesosphere in the spring of 1992, Geophys. Res. Lett., 23, 23252328, 1996.

Bernath, P. F., McElroy, C. T., Abrams, M. C., Boone, C. D., Butler, M., Camy-Peyret, C., Carleer, M., Clerbaux, C., Coheur, P.-F., Colin, R., DeCola, P., DeMazière, M., Drummond, R., Dufour, D., Evans, W. F. J., Fast , H., Fussen, D., Gilbert, K., Jennings, D. E., Llewellyn, E. J., Lowe, R. P., Mahieu, E., McConnell, J. C., McHugh, M., McLeod, S. D., Michaud, R., Midwinter, C., Nassar, R., Nichitiu, F., Nowlan, C., Rinsland, C. P., Rochon, Y. J., Rowlands, N., Semeniuk, K., Simon, P., Skelton, R., Sloan, J. J., Soucy, M.-A., Strong, K., Tremblay, P., Turnbull, D., Walker, K. A., Walkty, I., Wardle, D. A., Wehrle, V., Zander, R., and Zou, J.: Atmospheric Chemistry Experiment (ACE): Mission overview, Geophys. Res. Lett., 32, L15S01, doi:10.1029/2005GL022386, 2005.

Blum, U. and Fricke, K. H.: The Bonn University lidar at the Esrange: Technical description and capabilities for atmospheric research, Ann. Geophys., 23(5), 1645-1658, 2005.

Bonazzola, M. and Haynes, P. H.: A trajectory-based study of the tropical tropopause region, J. Geophys. Res., 109, D20112, doi:10.1029/2003JD004356, 2004.

Brasseur, G. and Solomon, S.: Aeronomy of the middle atmosphere, D. Reidel Publishing Company, Dordrecht Boston Lancaster Tokyo, 1998.

Brewer, A. W.: Evidence for a world circulation provided by the measurements of helium and water vapour distribution in the stratosphere, Q. J. Roy. Meteor. Soc., 75, 351-363, 1949.

Croskey, C. L., Kämpfer, N., Belivacqua, R. M., Hartmann, G. K., Kunzi, K. F., Schwartz, P. R., Olivero, J. J., Puliafito, S. E., Aellig, C., G., Umlauft, Waltman, W. B., and Degenhardt, W.: The Millimeter-Wave Atmospheric Sounder (MAS): A shuttle based remote sensing experiment, IEEE T. Microw. Theory, 40, 10901100, 1992.

de la Noë, J., Ovarlez, J., Ovarlez, H., Schiller, C., Lautié, N., Ricaud, P., Urban, J., Feist, D. G., Zalesak, L., Kämpfer, N., Ridal, M., Murtagh, D., Lindner, K., Klein, U., Künzi, K., Forkman, P., Winnberg, A., Hartogh, P., and Engel, A.: Water vapour distribution inside and outside the polar vortex during THESEO, Fifth European Symposium on Stratospheric Ozone, St. Jean de Luz/France, Pollution Research Report, edited by: Harries, N. R. P., Guirlet, M., and Amanatidis, G. T., 73, 558-561, 2000.
Dörnbrack, A., Leutbecher, M., Reichardt, J., Behrendt, A., Müller, K.-P., and Baumgarten, G.: Relevance of mountain wave cooling for the formation of polar stratospheric clouds over Scandinavia: Mesoscale dynamics and observations for January 1997: J. Geophys. Res., 106(D2), 1569-1582, doi:10.1029/2000JD900194, 2001.

Engel, A., Bönisch, H., Brunner, D., Fischer, H., Franke, H., Günther, G., Gurk, C., Hegglin, M., Hoor, P., Königstedt, R., Krebsbach, M., Maser, R., Parchatka, U., Peter, T., Schell, D., Schiller, C., Schmidt, U., Spelten, N., Szabo, T., Weers, U., Wernli, H., Wetter, T., and Wirth, V.: Highly resolved observations of trace gases in the lowermost stratosphere and upper troposphere from the Spurt project: an overview, Atmos. Chem. Phys., 6(2), 283-301, 2006.

Eyring, V., Butchart, N., Waugh, D. W., Akiyoshi, H., Austin, J., Bekki, S., Bodeker, G. E., Boville, B. A., Brühl, C., Chipperfield, M. P., Cordero, E., Dameris, M., Deushi, M., Fioletov, V. E., Frith, S. M., Garcia, R. R., Gettelman, A., Giorgetta, M. A., Grewe, V., Jourdain, L., Kinnison, D. E., Mancini, E., Manzini, E., Marchand, M., Marsh, D. R., Nagashima, T., Newman, P. A., Nielsen, J. E., Pawson, S., Pitari, G., Plummer, D. A., Rozanov, E., Schraner, M., Shepherd, T. G., Shibata, K., Stolarski, R. S., Struthers, H., Tian, W., and Yoshiki, M.: Assessment of temperature, trace species, and ozone in chemistry-climate model simulations of the recent past, J. Geophys. Res., 111, D22308, doi:10.1029/2006JD007327, 2006.

Fueglistaler, S., Dessler, A. E., Dunkerton, T. J, Folkins, I., Fu, Q., and Mote, P. W.: The tropical tropopause layer, Rev. Geophys., 47(1), RG1004, doi:10.1029/2008RG000267, 2009.

Gordley, L. L., Hervig, M. E., Fish, C., Russell, J. M., Bailey, S., Cook, J., Hansen, S., Shumway, A., Paxton, G., Deaver, L., Marshall, T., Burton, J., Magill, B., Brown, C., Thompson, E., and Kemp, J.: The solar occultation for ice experiment, J. Atmos. Sol.-Terr. Phys., 71, 300-315, 2009.

Gumbel, J.: Rocket-borne optical measurements of minor constituents in the middle atmosphere, $\mathrm{PhD}$ thesis, Stockholm University, ISBN: 91-7153-693-0, 1997.

Hirota, I. and Niki,T.: Inertia-gravity waves in the troposphere and stratosphere observed by the MU radar, Meteor. Soc. Jpn., 64, 995-999, 1986.

Holton, J. R., Haynes, P. H., McIntyre, M. E., Douglass, A. R., Rood, R. B., and Pfister, L.: Stratosphere-troposphere exchange, Rev. Geophys., 33(4), 403-439, 2005.

Horányi, M., Robertson, S., Smiley, B., Gumbel, J., Witt, G., and Walch, B.: Rocket-borne mesospheric measurement of heavy charge carriers, Geophys. Res. Lett., 27, 3825-3828, 2000.

Kelly, K. K., Tuck, A. F., Murphy, D. M., Proffitt, M. H., Fahey, D. W., Jones, R. L., McKenna, D. S., Loewenstein, M., Podolske, J. R., Strahan, S. E., Ferry, G. V., Chan, K. R., Vedder, J. F., Gregory, G. L., Hypes, W. D., McCormick, M. P., Browell, E. V., and Heidt, L. E.: Dehydration in the lower Antarctic stratosphere during late winter and early spring 1987, J. Geophys. Res., 94, 11317-11357, 1989.

Khaplanov, M., Astakhov, V., Lukjanov, A., Kretova, M., and Yushkov, V.: Fluorescent hygrometer for middle atmosphere measurements; Proceedings of the 19th Annual European Meeting on Atmospheric Studies by Optical Methods, 540-545, 1992.

Khaplanov, M., Gumbel, J., Wilhelm, N., and Witt, G.: Hygrosonde - A direct measurement of water vapour in the stratosphere and 
mesosphere, Geophys. Res. Lett., 23, 1645-1648, 1996.

Khaplanov, M., Gumbel, J., Witt, G., and Kirkwood, S.: Studies of troposphere/stratosphere humidity structures during the Skerries balloon programme, Proceedings of the 15th ESA Symposium on European Rocket and Balloon Programmes and Related Research (ESA SP-471), 283-286, 2001.

Kley, D. and Stone, E. J.: Measurement of water vapour in the stratosphere by photodissociation with Ly $\alpha\left(1216^{\circ}\right)$ light, Rev. Sci. Instrum., 49, 691-697, 1978.

Lait, L. R.: An alternative form for potential vorticity; J. Atmos. Sci., 51(12), 1754-1759, 1993.

Lelieveld, J., Brühl, C., Jöckel, P., Steil, B., Crutzen, P. J., Fischer, H., Giorgetta, M. A., Hoor, P., Lawrence, M. G., Sausen, R., and Tost, H.: Stratospheric dryness: model simulations and satellite observations, Atmos. Chem. Phys., 7(5), 1313-1332, 2007.

Lucke, R. L., Korwan, D. R., Bevilacqua, R. M., Hornstein, J. S., Shettle, E. P., Chen, D. T., Daehler, M., Lumpe, J. D., Fromm, M. D., Debrestian, D., Neff, B., Squire, M., König-Langlo, G., and Davies, J.: The Polar Ozone and Aerosol Measurement (POAM) III instrument and early validation results, J. Geophys. Res., 104(D15), 18785-18799, 1999.

M. Maturilli, Fierli, F., Yushkov, V., Lukyanov, A., Khaykin, S., and Hauchecorne, A.: Stratospheric water vapour in the vicinity of the Arctic polar vortex, Ann. Geophys., 24, 1511-1521, 2006, http://www.ann-geophys.net/24/1511/2006/.

Mote, P. W., Rosenlof, K. H., McIntyre, M. E., Carr, E. S., Gille, J. C., Holton, J. R., Kinnersley, J. S., Pumphrey, H. C., Russell III, J. M., and Waters, J. W.: An atmospheric tape recorder: The imprint of tropical tropopause temperatures on stratospheric water vapor, J. Geophys. Res., 101(D2), 3989-4006, 1996.

Naujokat, B., Krüger, K., Matthes, K., Hoffmann, J., Kunze, M., and Labitzke, K.: The early major warming in December 2001 - exceptional?, Geophys. Res. Lett., 29(21), 2023, doi:10.1029/2002GL015316, 2002.

Nash, E. R., Newman, P. A., Rosenfield, J. E., and Schoeberl, M. R.: An objective determination of the polar vortex using Ertel's potential vorticity, J. Geophys. Res., 101(D5), 9471-9478, 1996.

Nassar, R., Bernath, P. F., Boone, C. D., Manney, G. L., McLeod, S. D., Rinsland, C. P., Skelton, R. S., and Walker, K. A.: ACE-FTS measurements across the edge of the winter 2004 Arctic vortex, Geophys. Res. Lett., 32, L15S05, doi:10.1029/2005GL022671, 2005.

Nedoluha, G. E., Bevilacqua, R. M., Gomez, R. M., Waltman, W .B., Hicks, B. C., Thacker, D. L., and Matthews, W. A.: Measurements of water vapor in the middle atmosphere and implications for mesospheric transport, J. Geophys. Res., 101(D16), 21183-21194, doi:10.1029/96JD01741, 1996.

Nedoluha, G. E., Bevilacqua, R. M., and Hoppel, K. W.: POAM III measurements of dehydration in the Antarctic and comparisons with the Arctic, J. Geophys. Res., 107(D20), 8290, doi:10.1029/2001JD001184, 2002.

Nedoluha, G. E., Bevilacqua, R. M., Gomez, R. M., Hicks, B. C., Russell III J. M., and Connor, B. J.: An evaluation of trends in middle atmospheric water vapor as measured by HALOE, WVMS, and POAM, J. Geophys. Res., 108(D13), 4391, doi:10.1029/2002JD003332, 2003.

Oltmans, S. J., Vömel, H., Hofmann, D. J., Rosenlof, K. H., and Kley, D.: The increase in stratospheric water vapor from balloonborne, frostpoint hygrometer measurements at Washington, D.C. and Boulder, Colorado, Geophys. Res. Lett., 27(21), 3453-3456 2000.

Randel, W. J., Wu, F., Oltmans, S. J., Rosenlof, K. H., and Nedoluha, G. E.: Interannual changes of stratospheric water vapor and correlations with tropical tropopause temperatures; J. Atmos. Sci., 61(17), 2133-2148, 2004.

Reid, S. J. and Vaughan, G.: Lamination in ozone profiles in the lower stratosphere, Q. J. Roy. Meteor. Soc., 117, 825-844, 1991.

Rex, M., Salawitch, R. J., von der Gathen, P., Harris, N. R. P., Chipperfield, P., and Naujokat, B.: Arctic ozone loss and climate change; Geophys. Res. Lett., 31, L04116, doi:10.1029/2003GL018844, 2004.

Robertson, S., Horanyi, M., and Sternovsky, Z.: Rocket-borne probes for charged mesospheric aerosol particles, Proceedings of 35th COSPAR Scientific Assembly, Paris/France, 1887, 2004.

Rosenlof, K. H., Chiou, E.-W., Chu, W. P., Johnson, D. G., Kelly, K. K., Michelsen, H. A., Nedoluha, G. E., Remsberg, E. E., Toon, G. C., and McCormick, M. P.: Stratospheric water vapor increases over the past half-century, Geophys. Res. Lett., 28(7), 1195-1198, 2001.

Rosenlof, K. H. and Reid, G. C.: Trends in the temperature and water vapor content of the tropical lower stratosphere: Sea surface connection, J. Geophys. Res., 113(D6), doi:10.1029/2007JD009109, 2008.

Scherer, M., Vmel, H., Fueglistaler, S., Oltmans, S. J., and Staehelin, J.: Trends and variability of midlatitude stratospheric water vapour deduced from the re-evaluated Boulder balloon series and HALOE, Atmos. Chem. Phys., 8(5), 1391-1402, 2008.

Schmidlin, F. J., Lee, H. S., and Michel, W.: The inflatable sphere: A technique for the accurate measurements of middle atmospheric temperatures, J. Geophys. Res., 96, 22673-22682, 1991.

Seele, C. and Hartogh, P.: Water vapour of the polar middle atmosphere: Annual variation and summer mesosphere conditions as observed by ground-based microwave spectroscopy, Geophys. Res. Lett., 25, 2133-2136, 1999.

Sherwood, S. C. and Dessler, A. E.: On the control of stratospheric humidity, Geophys. Res. Lett., 27, 2513-2516, 2000.

Sonnemann, G. R., Grygalashvyly, M., and Berger, U.: Autocatalytic water vapor production as a source of large mixing ratios within the middle to upper mesosphere, J. Geophys. Res., 110, D15303, doi:10.1029/2004JD005593, 2005.

Stratospheric Processes and Their Role in Climate (SPARC), SPARC Assessment of upper tropospheric and stratospheric water vapour, edited by: Kley, D., Russell III, J. M., and Philips, C., WMO/ICSU/IOC World Climate Research Programme, Geneva, Switzerland, 2000.

Summers, M. E., Conway, R. R., Siskind, D. E., Stevens, M. H., Offermann, D., Riese, M., Preusse, P., Strobel, D. F., and Russell III, J. M.: Implications of satellite $\mathrm{OH}$ observations for middle atmospheric $\mathrm{H}_{2} \mathrm{O}$ and ozone Science, 277, 1967-1970, 1997.

Summers, M. E., Conway, R. R., Englert, C. R., Siskind, D. E., Stevens, M. H., Russell III, J. M., Gordley, L. L., and McHugh, M. J.: Discovery of a water vapor layer in the Arctic summer mesosphere: Implications for polar mesospheric clouds, Geophys. Res. Lett., 28(18), 3601-3604, 2001.

Uppala, S. M., Kållberg, P. W., Simmons, A. J., Andrae, U., Bechtold, V. Da Costa, Fiorino, M., Gibson, J. K., Haseler, J., Hernandez, A., Kelly, G. A., Li, X., Onogi, K., Saarinen, S., Sokka, N., Allan, R. P., Andersson, E., Arpe, K., Balmaseda, M. A., 
Beljaars, A. C. M., Berg, L. Van De, Bidlot, J., Bormann, N., Caires, S., Chevallier, F., Dethof, A., Dragosavac, M., Fisher, M., Fuentes, M., Hagemann, S., Hólm, E., Hoskins, B. J., Isaksen, L., Janssen, P. A. E. M., Jenne, R., McNally, A. P., Mahfouf, J.-F., Morcrette, J.-J., Rayner, N. A., Saunders, R. W., Simon, P., Sterl, A., Trenberth, K. E., Untch, A., Vasiljevic, D., Viterbo, P., Woollen, J.: The ERA-40 re-analysis, Q. J. Roy. Meteor. Soc., 131(612), 2961-3012, 2005. von Zahn, U. and Berger, U.: Persistent ice cloud in the midsummer upper mesosphere at high latitudes, Three-dimensional modeling and cloud interactions with ambient water vapour, J. Geophys. Res., 108(D7), 8451, doi:10.1029/2002JD002409, 2003.

Vömel, H., Oltmans, S. J., Hofmann, D. J., Deshler, T., and Rosen, J. M.: The evolution of the dehydration in the Antarctic stratospheric vortex, J. Geophys. Res., 100, 13919-13926, 1995. 